\title{
UNDERSTANDING RARITY IN A NARROW ENDEMIC BEGONIA THROUGH BIOLOGICAL COMPARISON WITH A COMMON SPECIES
}

\author{
Chan YM*, Chua LSL, Lee SL \& Lee CT \\ Forest Research Institute Malaysia, 52109 Kepong, Selangor, Malaysia \\ *yokemui@frim.gov.my
}

Submitted March 2019; accepted July 2019

\begin{abstract}
Rare endemics usually have high risk of threats and extinction and often require conservation urgency. Hence, understanding the causes and consequences of rarity is the basis for sound conservation efforts. Here, we compare the reproductive fecundity, mating system, morphological traits, demography, microclimate and genetic diversity between a rare (Begonia herveyana) and a common (B. maxwelliana) herbaceous congener to investigate whether these attributes contribute to rarity in Begonia. The reproductive fecundity, mating system, microclimate and demographic structure of both species were similar and thus, did not explain well the causes of rarity. Both species recorded fruit sets of 55-67\%, adopted a mixed-mating system with outcrossing rates of approximately $90 \%$, established at microsites of high humidity and low light intensity, and showed a J-shaped demographic structure. However, both species differed in plant size and the level of genetic diversity. The plant size was bigger in $B$. maxwelliana and the genetic diversity of $B$. herveyana $\left(H_{\mathrm{E}}=0.113\right)$ was lower than that of $B$. maxwelliana $\left(H_{\mathrm{E}}=0.415\right)$. Rarity in $B$. herveyana could possibly be explained by the low level of genetic diversity, population decline and limited dispersal.
\end{abstract}

Keywords: Reproductive fitness, genetic diversity, mating system, demography, rare endemic

\section{INTRODUCTION}

In general consensus, there are three important biological attributes that define rarity, namely, abundance, habitat specificity and/or geographical range (Gaston 1997). Hence, a rare species would have low abundance or small population size or narrow geographical range. Similarly, narrow endemism is a form of rarity described by geographical range, ecological breadth and isolation (Kruckeberg \& Rabinowitz 1985).

Causes of rarity and narrow endemism include speciation or evolution (Kruckeberg \& Rabinowitz 1985, Chown 1997), microclimate, geographical isolation, soil properties, biotic interactions (Kruckeberg \& Rabinowitz 1985) and ecological differentiation (Lavergne et al. 2004). It is also argued that discontinuities caused by geological processes that give rise to various landforms, habitats or microclimates are the main causes of rare endemism (Kruckeberg \& Rabinowitz 1985). Another possible cause of rarity is the difference in levels of genetic diversity which allows selection and adaptation to environmental changes (Frankham et al. 2002).
The majority of more than 200 species of Begonia in Malaysia are rare endemics confined to very small local scales with small population sizes (Kiew 2005, Kiew et al. 2015). In Peninsular Malaysia, 48 of 54 species of Begonia are endemics $(88 \%)$, of which $57 \%$ are threatened and one extinct (Chua et al. 2009). There is a pressing need for their conservation because rare endemics are susceptible to higher risks of extinction (Saw et al. 2010).

The genus Begonia may offer insights to the causes of rarity in rare endemics. Here, we refer rare/narrow endemics as those with restricted distribution and habitat. To investigate the causes of rarity, we compared the biological attributes of two closely related congeners i.e., Begonia maxwelliana King and B. herveyana King. Despite both having similar habitat, morphology, pollination syndrome and mode of dispersal, $B$. maxwelliana has a wider distribution range and is more common than the locally restricted $B$. herveyana. We asked these questions: (1) Are both species similar in levels of genetic diversity, mating system and reproductive fecundity? (2) 
Which of these factors are likely to contribute to rarity in $B$. herveyana? We also investigated the microclimate, demography, and plant traits of both species for a more holistic understanding of their life histories.

\section{MATERIALS AND METHODS}

\section{Study species and sites}

Begonia herveyana and B. maxwelliana are perennial herbaceous plants with rhizomatous roots. Both are mainly confined to upper stream valleys in the forests and grow on rocks (lithophytic). They are also localised in high densities, contributed by limited dispersal and clustering of adults because of clonal growth. Both species are also endemic to
Peninsular Malaysia. Begonia maxwelliana is more widespread (mainly in Perak) than B. herveyana which is only found in Melaka and Johor (i.e. Pulau Tinggi) (Kiew 2005) (Figure 1). At Pulau Tinggi which is an island off the east coast, only two adult plants and some juveniles of $B$. herveyana were found in 2009.

Six study sites, all on granitic formations, were selected: Larut, Chepor, Gopeng and Tapah in Perak, and Batang Melaka and Senggeh in Melaka (Figure 1). All sites are located within forest reserves of the tropical lowland rainforest (119-668 $\mathrm{m}$ altitude), except Larut which is in the lower montane forest (928 $\mathrm{m}$ altitude).

The current population of $B$. herveyana in Melaka (Batang Melaka and Senggeh) is small, fragmented and threatened by habitat

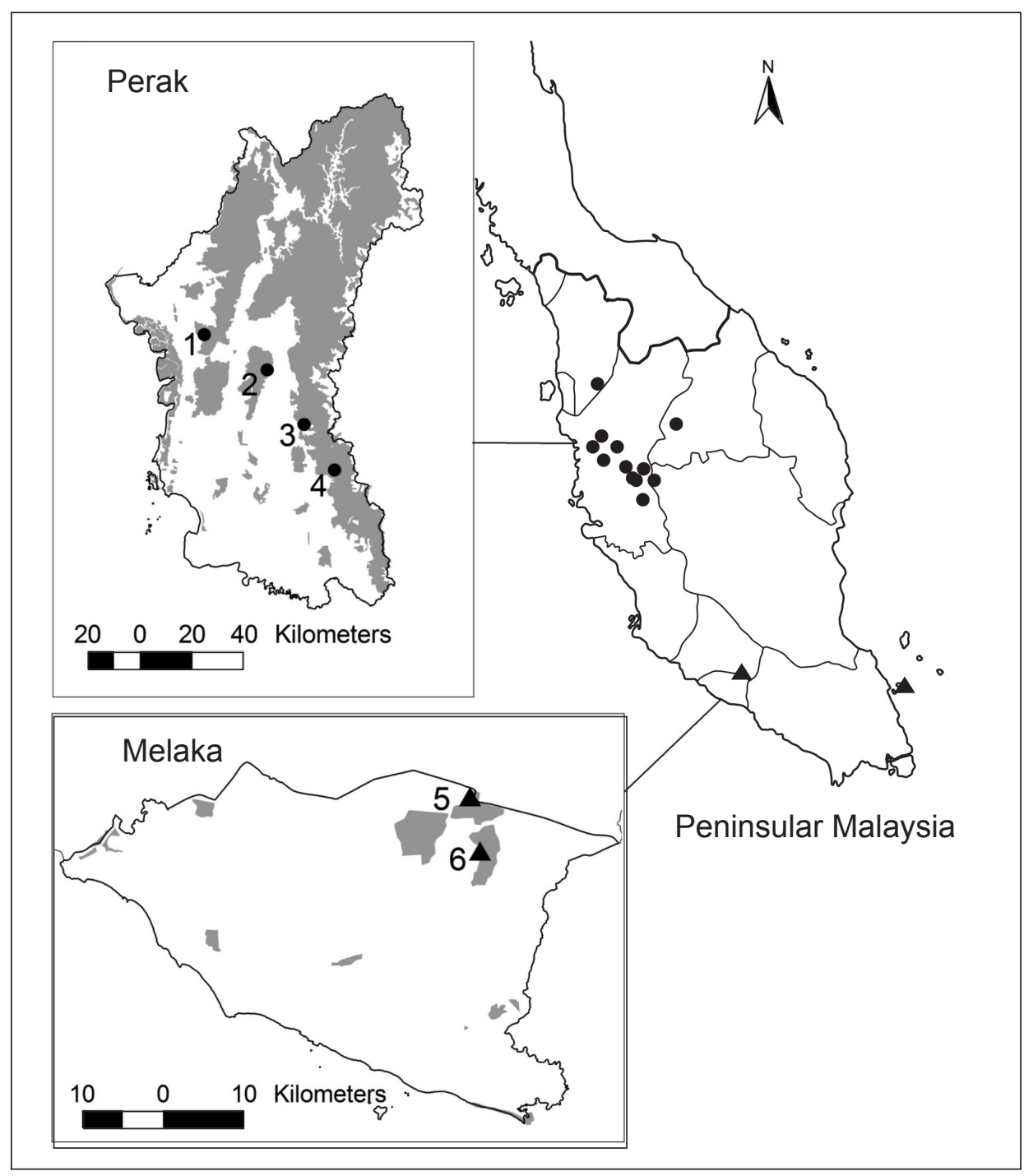

Figure 1 Distribution of Begonia maxwelliana $(\bullet)$ and B. herveyana $(\boldsymbol{\Delta})$ in Peninsular Malaysia, and sampling sites in the states of Perak and Melaka: 1) Larut, 2) Chepor, 3) Gopeng, 4) Tapah, 5) Batang Melaka and 6) Senggeh; forest in grey 
degradation. Senggeh has about 200 adults whereas Batang Melaka has only about 10 . The Senggeh population thrives at an altitude of 119-175 m. Mean temperature of the area was $26.2 \pm 1.1{ }^{\circ} \mathrm{C}$ (standard deviation), while mean light intensity and relative humidity was $2649.5 \pm$ $2193.4 \mathrm{~lx}$ and $92.5 \pm 3.9 \%$ respectively ( $\mathrm{N}$ readings $=127$, measured every $5 \mathrm{~min}$ in two days from 9.35 a.m.-4.20 p.m. in July 2011 using HOBO dataloggers). Begonia maxwelliana was found at altitudes 150-1218 $\mathrm{m}$ and the population size of all study sites combined was estimated at about 2000 adults. Mean temperature from 10.00 a.m. to 2.00 p.m., measured in 2014 , was $21.2-26.7^{\circ} \mathrm{C}$ while relative humidity was $84.8-88.6 \%$ (Chan et al. 2018).

\section{Reproductive fecundity}

Flowering and fruiting of both species were monitored every two weeks at all sites except Tapah and Batang Melaka. The population of B. herveyana in Senggeh was observed from August 2007 to August 2009 whereas the selected populations of B. maxwelliana were observed from June to September 2014. The number of plants and inflorescences (in brackets) sampled at Senggeh, Chepor, Gopeng and Larut were 120 (757), 60 (125), 58 (168) and 44 (84) respectively. We counted the mean number of female flowers per inflorescence per plant $\left(\mathrm{N}_{\mathrm{flo}}\right)$ and for those inflorescences that set fruits, the mean number of mature fruits per infructescence per plant $\left(\mathrm{N}_{\mathrm{fru}}\right)$. A fruit was considered mature when the green capsule turned brown. We calculated the fruit set for both species as the proportion of female flowers that developed into mature fruits, and tested the differences by using nonparametric Wilcoxon rank test. The $\mathrm{N}_{\text {flo }}$ and $\mathrm{N}_{\text {fru }}$ were not tested for differences between species because the distributions were not normal and the variances were not homogeneous even after transformation.

To measure seed mass, we collected and dried ripe, undehisced fruits of $B$. herveyana and $B$. maxwelliana $(\mathrm{N}=9$ and 26 plants respectively) in silica gel for at least 1 week before weighing them with a digital balance $(0.001 \mathrm{~g}$ accuracy). The sample size for $B$. herveyana was small because of low fruiting frequency in the population during the sampling period from 2015 to 2017. Seed mass was calculated as the weight of a capsule containing seeds minus the weight of the capsule with seeds emptied. Wilcoxon rank test was used to test the differences in seed mass between species. To estimate the number of seeds per capsule, we counted two capsules of $B$. maxwelliana and $B$. herveyana each, for their seeds.

We assessed the seed viability via seed germination success. Prior to sowing, we desicated seeds of $B$. herveyana $(\mathrm{N}$ plant $=10)$ and $B$. maxwelliana $(\mathrm{N}$ plant $=42)$ in silica gel for at least one week. A petri dish lined with a thin layer of sphagnum moss was divided into four segments. For each segment, 20 well-developed seeds from a mother plant were sown and incubated at room temperature $\left(25-29{ }^{\circ} \mathrm{C}\right)(\mathrm{N}$ replicate $=$ $1-2)$. Batch allocation of seeds in a petri dish was randomised. Number of seeds that germinated (defined as the emergence of the first pair of leaves) were counted weekly for eight weeks. The dataset in percentage of germination was arcsine transformed prior to $t$ test between species.

\section{Genetic diversity}

Leaf samples were collected from 52 reproductive plants of B. herveyana (Batang Melaka $=4$ and Senggeh $=48$ ). To avoid sampling of clones, we selected only one plant per cluster or boulder, or sampled at least $1 \mathrm{~m}$ between plants. DNA was extracted either from silica-dried $(0.05 \mathrm{~g})$ or fresh $(0.1 \mathrm{~g})$ leaves following a modified protocol for DNeasy Plant Mini Kit (QIAGEN), using twice the recommended amount of buffers AP1 and AP2. Sixteen polymorphic microsatellite markers were used for multiplex genotyping as described in Chan et al. (2018). Genetic data were analysed using GenAlEx 6.5 to estimate the genetic diversity parameters. The same parameters for B. maxwelliana have been reported in Chan et al. (2018) and are compared here with those of B. herveyana.

\section{Mating system}

Seeds were collected from maternal plants of $B$. herveyana $(\mathrm{N}=8$, in May-July 2017) and $B$. maxwelliana ( $\mathrm{N}=9$, in July-September 2014). The seeds were incubated on moist sphagnum moss in petri dishes at room temperature $\left(26-29{ }^{\circ} \mathrm{C}\right)$. Seedlings were harvested after 4 weeks, and DNA samples were extracted following the modified CTAB miniprep protocols (Chan et al. 2018). We used five microsatellite markers developed in Chan et al. (2015) and Chan et al. (2018) for 
multiplex genotyping, namely, $B V 05, B V 03, B V 54$, BV28 and BV68.

PCR amplifications were conducted in $8 \mu \mathrm{L}$ mixture of c. $5 \mathrm{ng}$ template DNA, primer mix containing $0.03 \mu \mathrm{M}$ of each primer and Type-It multiplex PCR master mix. The mixture was denatured at $94{ }^{\circ} \mathrm{C}$ for $4 \mathrm{~min}$, followed by 40 cycles of $94{ }^{\circ} \mathrm{C}$ for $1 \mathrm{~min}, 55^{\circ} \mathrm{C}$ annealing temperature for $30 \mathrm{~s}$ and $72{ }^{\circ} \mathrm{C}$ for $40 \mathrm{~s}$, and an extension of $72{ }^{\circ} \mathrm{C}$ for $30 \mathrm{~min}$, using a GeneAmp PCR System 9700. The PCR products, with ROX 400 as the size standard, were analysed using an ABI 3130xl Genetic Analyzer. A total of 387 and 398 seedlings of B. herveyana and B. maxwelliana respectively (an average of 46 seedlings per family), were genotyped using the software GeneMarker version 2.6.4.

Mating system parameters were estimated using MLTR ver. 3.2 (Ritland 2002) which assumed mixed-mating model. The NewtonRaphson method was applied for maximum likelihood estimates with resampling of families (1000 bootstraps). Estimation of pollen gene frequency was constrained to equal ovule gene frequency. The maternal genotypes of six of the 17 families, which were unknown, were inferred by the software.

\section{Microclimate}

At each site of Chepor, Gopeng and Senggeh, HOBO dataloggers were placed at the microsite where most seedlings were found (i.e. establishment site) for hourly measurements of relative humidity, temperature and light intensity. The relative humidity dataloggers were sheltered from rain using half cut plastic bottles with the sensors facing down to prevent malfunction of the loggers.

Light availability in the forest understorey was assessed at Chepor, Gopeng, Larut and Senggeh in year 2016, by using a canopy-scope according to Brown et al. (2000). The biggest canopy gap was assessed at each microsite by counting the number of dots out of 25 on the screen of the canopy-scope that coincided with the gap.

\section{Demography}

The population of $B$. herveyana at Senggeh and three representative subpopulations of B. maxwelliana at Chepor were selected for demographic study because they were similar in population size and habitat. Censuses of both populations were conducted once in September 2014 and repeated in April 2016 to estimate demographic composition, recruitment and mortality. In 2014, a total of 335 and 195 individuals were recorded for Senggeh and Chepor respectively. In 2016, 13 of the plants in Chepor were not traceable and were excluded from the analysis.

Plants were tagged and classified into life stages based on leaf size and flowering or fruiting events. For seedlings, only those having at least one leaf with $>1 \mathrm{~cm}$ width were tagged. For $B$. maxwelliana, an adult was defined as having leaf width $\geq 10 \mathrm{~cm}$, a juvenile with leaf width $3-10 \mathrm{~cm}$ or having a rhizome diameter $>0.3 \mathrm{~cm}$. For $B$. herveyana, the leaf width of a juvenile was $<$ $8 \mathrm{~cm}$ and that for a seedling was $<2 \mathrm{~cm}$. A plant was considered an adult if it had a thick $(>0.5 \mathrm{~cm})$ or long rhizome (usually $>3 \mathrm{~cm}$ ). Clones were considered as one individual or genet. A reproductive plant was indicated either by the presence of flowering/fruiting or by an old infructescence in the plant. An adult plant surrounded by seedlings was also considered reproductive when no other adult plants were seen nearby.

\section{Plant traits}

Thirteen morphological traits were recorded from 36 reproductive plants of $B$. herveyana at Senggeh with two replicates per individual whenever possible, except for rhizome which had only one reading. Same traits were measured respectively on $61,66,42$ and 43 reproductive plants of B. maxwelliana (totalling 212 samples) at Chepor, Gopeng, Larut and Tapah. For leaf measurement, the biggest leaves were selected.

\section{Data analyses}

For the dataset of plant traits, exploratory and descriptive data analyses were conducted by using mean values calculated for each individual. For subsequent data analysis, female flower traits (with three variables) were excluded because of limited sample size (few female flowers were produced and some were missed as they only lasted less than one week). Data were analysed using the $\mathrm{R}$ statistical software and its relevant packages.

To test the differences in traits between species, we applied two-tailed $t$-tests for normally 
distributed and homogeneous variables. Variables with non-normal distributions were variously transformed to improve normality. We used the Welch $t$-test for variables with heterogeneous variances and/or unequal sample size, provided that the samples were normally distributed (Quinn \& Keough 2002). For variables with homogeneous variances but skewed distributions that could not be improved by transformation, non-parametric Wilcoxon test was used. Fruit length and male tepal width were not compared between species because the distributions were not normal and the variances were not homogeneous even after transformation.

\section{RESULTS}

\section{Microclimate}

At the establishment sites, means of daily average temperature and daily average humidity for the three sites did not differ much (Table 1). However, high fluctuations of relative humidity (96-100\%) and light intensity (261-5121 lx) were found at Chepor and Gopeng respectively (data not shown here). Light intensity was highest at Gopeng, especially in the afternoon at about 2.00 p.m. Mean canopy gap index was highest at Senggeh (18\%, Table 2). A gap index of 16 (i.e. 64\%) was recorded at one microsite in Chepor where a recent gap was created by a tree fall. In summary, both species were established at microsites with high humidity (defined here as
$>99 \%)$, moderate temperature $\left(24^{\circ} \mathrm{C}\right)$ and low light intensity (1000 lx).

\section{Demography}

During the study period, both populations of $B$. herveyana (i.e. Senggeh) and B. maxwelliana (i.e. Chepor) showed a skewed distribution with many adults and relatively few seedlings (Figure 2 ), indicating low recruitment or high seedling mortality. We recorded 35 reproductive plants in Senggeh and 45 in Chepor. In 2016, 10 and 18 seedlings were recruited at Senggeh and Chepor respectively. From 2014 to 2016, the mortality rate of Senggeh $(53 \%)$ was higher than that of Chepor (30\%), mainly caused by a drought event in Senggeh in early 2015. In Senggeh, the mortality rate of adults $(48 \%)$ was starkly higher than that of Chepor $(6 \%)$. Similarly, the mortality rate of seedlings and juveniles of Senggeh was also higher (54\%) compared with that of Chepor (32\%). In 2016, there were transitions of eight seedlings to the juvenile stage and one juvenile to the adult stage in Senggeh whereas in Chepor, five seedlings transited to the juvenile stage and four juveniles to the adult stage.

\section{Reproductive fecundity and plant traits}

Compared with $B$. maxwelliana, B. herveyana produced fewer $\mathrm{N}_{\text {flo }}$ and $\mathrm{N}_{\text {fru }}$ and had lower seed mass and viability, but had higher fruit set (Table

Table 1 Environmental parameters measured at seedling establishment sites

\begin{tabular}{llccccc}
\hline Species & Locality & $\begin{array}{c}\text { Temperature } \\
\left({ }^{\circ} \mathrm{C}\right)\end{array}$ & $\begin{array}{c}\text { Relative humidity } \\
(\%)\end{array}$ & $\begin{array}{c}\text { Light intensity } \\
(\mathrm{lx})\end{array}$ & $\begin{array}{c}\text { No. of } \\
\text { days }\end{array}$ & Date \\
\hline Begonia maxwelliana & Chepor & $24.0 \pm 0.5$ & $99.4 \pm 0.8$ & $923.7 \pm 191.5$ & 48 & Aug-Sep 2014 \\
& Gopeng & $23.5 \pm 0.6$ & $99.8 \pm 0.3$ & $1009.4 \pm 1005.9$ & 48 & Aug-Sep 2014 \\
B. herveyana & Senggeh & $24.0 \pm 0.4$ & $99.8 \pm 0.2$ & $938.4 \pm 397.3$ & 28 & Jan 2013 \\
\hline
\end{tabular}

Values are given as mean of daily average \pm standard deviation

Table 2 Canopy gap index at selected study sites

\begin{tabular}{lclllll}
\hline Site & No. of microsite & Mean & Mean $\%$ & Mode & Range & Date \\
\hline Chepor & 14 & 4.1 & 16.4 & 2 & $2-16$ & April 2016 \\
Gopeng & 11 & 2.6 & 10.4 & 3 & $1-4$ & August 2016 \\
Larut & 3 & 3.7 & 14.8 & NA & $2-5$ & April 2016 \\
Senggeh & 13 & 4.5 & 18.0 & 3 & $3-7$ & February 2016 \\
\hline
\end{tabular}

$\mathrm{NA}=$ not available 


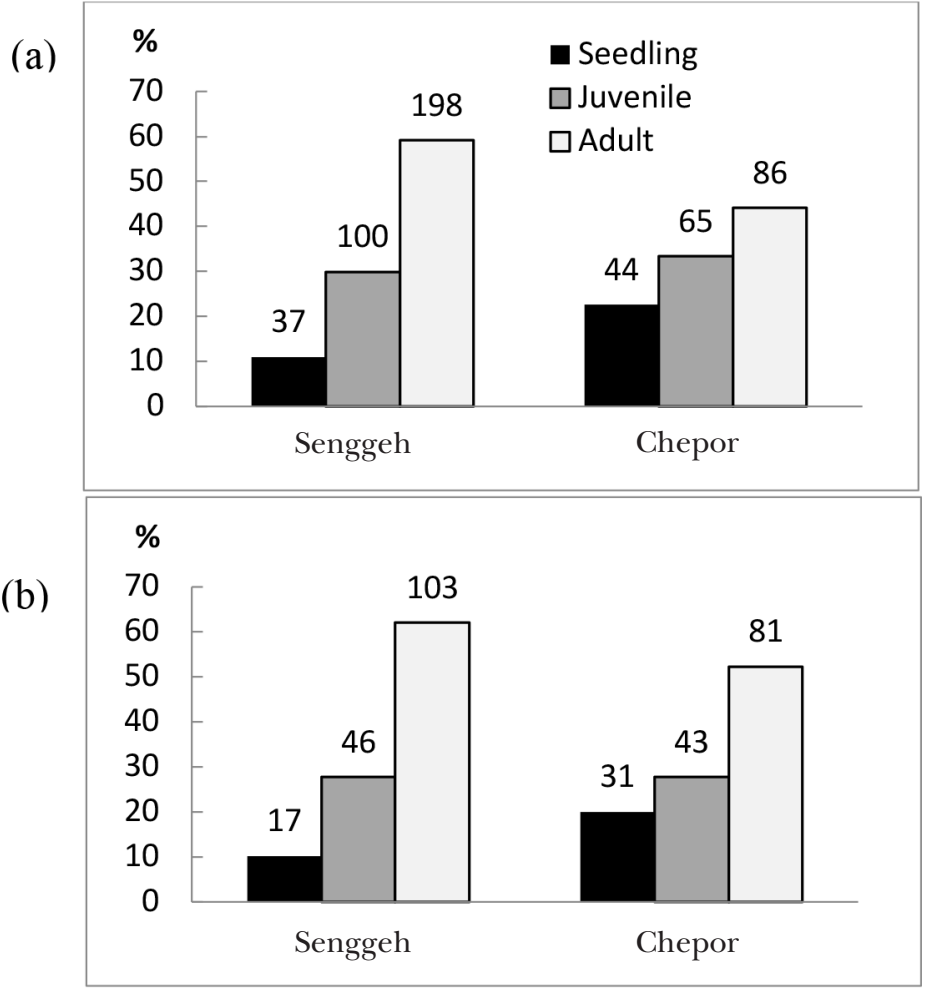

Figure 2 Demographic composition by percentage in Senggeh (Begonia herveyana) and Chepor (B. maxwelliana) in year (a) 2014 and (b) 2016; number of individuals are given at the top of bars

3). However, there were no significant differences between species for these variables. Seed viability of both species was between 51 and $66 \%$, and the estimated weight per seed was heavier in $B$. herveyana (Table 3). Plants were bigger in $B$. maxwelliana than $B$. herveyana, including the reproductive traits (male and female traits, and fruit size) (Table 4). Five of the eight traits tested were statistically different between species (i.e. two vegetative and three reproductive traits, Table 5).

\section{Genetic diversity and mating system}

The genetic diversity $\left(A_{\mathrm{a}}, H_{\mathrm{O}}\right.$ and $\left.H_{\mathrm{E}}\right)$ of $B$. maxwelliana was much higher than that of $B$. herveyana (Table 6). Both species showed positive inbreeding coefficients $\left(F_{\mathrm{IS}}\right)$, but $B$. herveyana had a higher value (0.173), indicating a general excess of homozygotes, which may be caused by inbreeding.

The multilocus outcrossing rate $\left(t_{\mathrm{m}}\right)$ of $B$. herveyana is comparable with that of $B$. maxwelliana (Table 7), indicating that both species have mixed-mating system and are predominantly outcrossing. Inference of biparental mating can be made from the comparison between $t_{\mathrm{m}}$ and the average of single locus outcrossing rates. Single locus outcrossing rate $\left(t_{\mathrm{s}}\right)$ is expected to be biased downward by any inbreeding in addition to selfing, thus the mean is expected to be lower than $t_{\mathrm{m}}$ when mating among relatives occurs. The negative value of biparental mating $\left(t_{\mathrm{m}}-t_{\mathrm{s}}\right)$ in $B$. herveyana $(-0.037)$ and the positive value in B. maxwelliana (0.115) indicated the presence of consanguineous mating only in $B$. maxwelliana. The probability that progeny from the same array are full sibs was higher in B. maxwelliana (0.385) than in B. herveyana $(0.159)$.

\section{DISCUSSION}

The results showed that the rare endemic, $B$. herveyana, had similar demographic structure, microclimate preference, mating system and reproductive fitness with the common species, B. maxwelliana. The predominantly outcrossing mating system was congruent with the reproductive morphology and behaviour of both species whereby neither in a flower nor in an inflorescence did male anthesis coincide with female receptivity. However, selfing within a plant 
Table 3 Comparison of reproductive fecundity between species

\begin{tabular}{lllc}
\hline & B. herveyana & B. maxwelliana & p-value $(\alpha=0.05)$ \\
\hline N plants (and inflorescences) with female flowers & $96(377)$ & $149(302)$ & \\
N plants fruited & 90 & 121 & \\
Mean N $_{\text {flo }}{ }^{*}$ & $2.2 \pm 0.9$ & $3.7 \pm 3.1$ & \\
Mean fruit set per plant (\%) $_{\text {Mean N }}{ }_{\text {fru }}$ & $65.9 \pm 30.7$ & $55.5 \pm 36.6$ & 0.050 \\
Mean seed mass (g) & $1.9 \pm 0.8$ & $2.3 \pm 1.7$ & \\
Mean seed viability (\%) & $0.019 \pm 0.017$ & $0.026 \pm 0.016$ & 0.218 \\
Estimated seeds per capsule & $51.0 \pm 39.3$ & $65.6 \pm 9.3$ & 0.217 \\
Estimated weight per seed $(\mathrm{g})$ & $3607-4196$ & $1219-3905$ & \\
\hline
\end{tabular}

$\mathrm{N}_{\text {flo }}=$ number of female flowers per inflorescence per plant, $\mathrm{N}_{\text {fru }}=$ number of mature fruits per inflorescence per plant; calculated values are means \pm standard deviations

Table 4 Quantitative morphological traits

\begin{tabular}{llllll}
\hline Trait $(\mathrm{cm})$ & \multicolumn{1}{c}{ B. herveyana } & & \multicolumn{2}{c}{ B. maxwelliana } \\
\cline { 2 - 3 } \cline { 5 - 6 } Leaf length & Mean $\pm \mathrm{SD}$ & $\mathrm{N}$ & & Mean $\pm \mathrm{SD}$ & $\mathrm{N}$ \\
Leaf petiole length & $18.90 \pm 2.58$ & 36 & & $17.86 \pm 3.12$ & 207 \\
Leaf width & $20.34 \pm 5.16$ & 36 & & $30.95 \pm 10.75$ & 207 \\
Rhizome diameter & $11.35 \pm 1.84$ & 36 & & $17.90 \pm 3.81$ & 207 \\
Male tepal length & $1.14 \pm 0.25$ & 36 & & $1.12 \pm 0.26$ & 208 \\
Male tepal width & $2.37 \pm 0.35$ & 31 & & $3.32 \pm 0.80$ & 165 \\
Stamen diameter & $2.33 \pm 0.35$ & 31 & & $2.86 \pm 0.69$ & 165 \\
Female tepal length & $0.69 \pm 0.09$ & 31 & & $0.55 \pm 0.10$ & 164 \\
Female tepal width & $1.89 \pm 0.15$ & 6 & & $2.74 \pm 0.64$ & 67 \\
Stigma diameter & $1.81 \pm 0.32$ & 6 & & $2.67 \pm 0.63$ & 67 \\
Fruit length & $0.65 \pm 0.18$ & 6 & & $0.80 \pm 0.14$ & 67 \\
Fruit width & $1.99 \pm 0.21$ & 22 & & $2.46 \pm 0.33$ & 173 \\
Peduncle length & $1.47 \pm 0.14$ & 22 & & $1.73 \pm 0.29$ & 173 \\
\hline
\end{tabular}

Table 5 Statistics for trait comparison between species

\begin{tabular}{lcclcl}
\hline Variable & Test statistics & $\mathrm{df}$ & $\mathrm{p}$-value & Test & Transformation \\
\hline Leaf length & 1.89 & 241 & 0.06 & $t$ & Normal \\
Leaf petiole length & -8.32 & 66.7 & $<0.001^{*}$ & Welch & Fourth root \\
Leaf width & -16.19 & 97.5 & $<0.001^{*}$ & Welch & Normal \\
Rhizome diameter & 0.43 & 242 & 0.67 & $t$ & Normal \\
Fruit width & 6.13 & 36.3 & $<0.001^{*}$ & Welch & Reciprocal square root \\
Male tepal length & -10.57 & 99.1 & $<0.001^{*}$ & Welch & Normal \\
Stamen diameter & 4314 & - & $<0.001^{*}$ & Wilcoxon & - \\
Peduncle length & -1.11 & 32.3 & 0.27 & Welch & Fourth root \\
\hline
\end{tabular}

*Significant difference at $\alpha=0.05$ 
Table 6 Comparison of genetic diversity parameters between species including mean number of alleles per locus $\left(A_{\mathrm{a}}\right)$, observed heterozygosity $\left(H_{\mathrm{O}}\right)$, unbiased expected heterozygosity $\left(H_{\mathrm{E}}\right)$, and inbreeding coefficient $\left(F_{\text {IS }}\right)$

\begin{tabular}{lllll}
\hline Species & $A_{\mathrm{a}}$ & $H_{\mathrm{O}}$ & $H_{\mathrm{E}}$ & $F_{\mathrm{IS}}$ \\
\hline B. herveyana & $1.75(0.17)$ & $0.099(0.038)$ & $0.113(0.040)$ & $0.173(0.085)$ \\
B. maxwelliana* & $4.00(0.25)$ & $0.378(0.029)$ & $0.415(0.031)$ & $0.058(0.021)$ \\
\hline
\end{tabular}

Standard errors are in parentheses; *Chan et al. (2018)

Table 7 Mating system parameters of B. herveyana in Senggeh and B. maxwelliana in Chepor

\begin{tabular}{lcccc}
\hline Species & $t_{\mathrm{m}}$ & $t_{\mathrm{s}}$ & $t_{\mathrm{m}}-t_{\mathrm{s}}$ & $r_{\mathrm{p}}$ \\
\hline B. herveyana & $0.907(0.127)$ & $0.943(0.144)$ & $-0.037(0.033)$ & $0.159(0.101)$ \\
B. maxwelliana & $0.896(0.053)$ & $0.781(0.095)$ & $0.115(0.049)$ & $0.385(0.113)$ \\
\hline
\end{tabular}

$t_{\mathrm{m}}=$ multilocus outcrossing rate, $t_{\mathrm{s}}=$ single locus outcrossing rate, $r_{\mathrm{p}}=$ index of multilocus paternity correlated mating; standard deviations are in parentheses

(geitonogamy) could be possible because there were occasions when the anthesis and receptivity coincided between two inflorescences (personal observation).

Fiedler (1987), Lavergne et al. (2004) and Rymer et al. (2005) reported that rare species had lower reproductive output (i.e. number of flowers, seed production and fruit set) than their widespread congeners. Contrary to this, our results showed that during the study period, B. herveyana and B. maxwelliana showed no significant differences in fecundity in particular, fruit set, seed mass and viability (Table 3). The small sample size for seed mass, however, was inadequate and a larger sample size was needed to confirm the finding. Fruit set and seed mass might fluctuate between seasons and years, depending on pollinator behaviour, pollination success, resource availability and abiotic factors such as weather, which were not studied here. Although seed viability also did not differ significantly between species, the fitness of seedlings until adulthood needs further investigation.

Plant size was larger in B. maxwelliana and we could not ascertain if this would indicate better photosynthetic and resource building capacity until further study. Narrow endemics are generally smaller and less competitive than their common congeners (Lavergne et al. 2004, Gabrielová et al. 2013).
In summary, our results support the view that many aspects of the reproductive biology and life history of locally common rare plants are similar to those of widespread congeners (Karron 1987, Lavergne et al. 2004, Gabrielová et al. 2013, Ruilova \& Marques 2016). Hence, these factors (i.e. reproductive biology, demographic structure and microclimate) are insignificant causes of rarity in $B$. herveyana. Based on our findings, genetic diversity in $B$. herveyana was lower than that of $B$. maxwelliana, and this could be one of the major contributing factors to rarity in $B$. herveyana. The level of genetic diversity of a species can be explained by geographical or evolutionary history (Binks et al. 2015, Fernández-Mazuecos et al. 2014). It is possible that $B$. herveyana was once widespread in the past, given its current disjunct distribution and extent (Melaka and Pulau Tinggi). It could possibly have gone through bottlenecks and selection to adapt to specific niches most beneficial for its survival. However, this postulation needs to be supported with phylogeographical studies to elucidate the history of the species studied. Other than selection (e.g. adaptation to a specific niche), small effective population size could also cause low genetic diversity in endemics (Kruckeberg \& Rabinowitz 1985). Thus, the observed low genetic diversity could also have resulted from population botttlenecks caused by anthropogenic deforestation. 
For a species to adapt to various local environments, high genetic diversity is advantageous. The higher levels of genetic diversity in $B$. maxwelliana could have been responsible for its occurrence in more diverse habitats such as lowland and highland niches compared with $B$. herveyana which is confined to lowland area. However, B. maxwelliana remains geographically endemic, which could be caused by limited seed dispersal through ballistic force (Chan et al. 2018). Begonia herveyana has the same mode of dispersal (Kiew 2005) but when coupled with low genetic diversity, it could have been less able to adapt to different habitats outside its range, causing it to be a narrow endemic.

Our results also support the general hypothesis that rare species have lower genetic diversity (Karron 1991, Gitzendanner \& Soltis 2000) but narrow endemics have been shown to have wide range of genetic diversity (FernándezMazuecos et al. 2014). According to Hamrick et al. (1991), geographic range (narrow or widespread) explains most of the genetic diversity (allozyme variation) in plants whereas life-history characteristics, breeding system and mode of reproduction explain at best, up to only $50 \%$ of the variance. Other contributing factors include different mutation rates, migration among populations and interactions among the above factors (Frankham et al. 2002). Literature shows that the genetic diversity of Begonia species range from 0.113 to 0.660 (Table 8 ), and it does not seem to correlate positively or negatively with population range. Begonia socotrana, a narrow endemic with a small population range, has much higher genetic diversity than those widespread species (B. heracleifolia and B. nelumbiifolia).

In $B$. herveyana, the current low level of genetic diversity is speculated to enhance its rarity and endemism. Genetic processes, including evolutionary and ecological processes, affect vital rates of a plant population (birth, growth and death). Genetic drift for example, can result in changes of allele number and frequency and levels of heterozygosity (Frankham et al. 2002). Allelic richness could contribute to population growth through its effect on evolutionary potential, or the ability of a species to respond to changes in its selective environment. Reduced heterozygosity can seriously affect population fitness (Reed \& Frankham 2003), and low genetic diversity may increase the mortality and reduce the growth of seedlings (Kolb \& Durka 2013).

How is $B$. herveyana going to maintain population fitness and avoid extinction given its low genetic diversity? For species with limited dispersal such as $B$. herveyana, local adaptation and local abundance (demographic resilience) (Kruckeberg \& Rabinowitz 1985, Williams et al. 2009) may be critical in maintaining population viability and fitness. Although $B$. herveyana is reproductively fit and has adapted well to its specific niche, the effects of small population size is a major concern in its conservation. The small population size of $B$. herveyana, apparently aggravated by anthropogenic activities, is currently highly susceptible to genetic drift and could be fixed for homozygotes. In Senggeh, the allele frequencies in 6 out of the 16 loci were already fixed at $P=1$ (this study). Such fixation of an allele is only reversible by mutation or introduction of new alleles via gene flow from another population. Several studies have demonstrated significant positive relationship between population size, fitness or genetic variation (Fischer \& Matthies 1998, Reed \& Frankham 2003, Leimu et al. 2006) although no correlation was found between reproductive fitness and genetic diversity in Muscari (Hornemann et al. 2012). Thus, there is an

Table 8 Genetic diversity $\left(H_{\mathrm{E}}\right)$ estimated for populations of Begonia species using microsatellite markers

\begin{tabular}{lcccl}
\hline Species & $H_{\mathrm{E}}$ & $\begin{array}{c}\text { Estimated population range } \\
(\mathrm{km})\end{array}$ & $\begin{array}{c}\text { No. of population } \\
\text { sampled }\end{array}$ & Reference \\
\hline B. herveyana & 0.113 & 7 & 2 & This study \\
B. heracleifolia & 0.276 & 680 & 13 & Twyford et al. (2014) \\
B. maxwelliana & 0.415 & 100 & 4 & Chan et al. (2018) \\
B. nelumbiifolia & 0.417 & 480 & 7 & Twyford et al. (2014) \\
B. sutherlandii & 0.461 & 300 & 9 & Hughes and Hollingsworth (2008) \\
B. socotrana & 0.660 & 15 & 10 & Hughes et al. (2003) \\
\hline
\end{tabular}


urgent need to protect the remaining population and habitats of $B$. herveyana from further decline. Degraded habitats should be rehabilitated if possible and ex situ conservation can be done through propagation and introduction of the populations to suitable habitats in other protected sites. Future work may include developing a conservation action plan that includes measures to increase its population size.

\section{CONGLUSIONS}

Many of the biological traits studied here were similar between B. herveyana and B. maxwelliana and did not explain well the causes of rarity. The genetic diversity, however, was much lower in $B$. herveyana. Rarity in $B$. herveyana could possibly be caused by low levels of genetic diversity, population decline and limited dispersal. To conserve the species, total protection of its habitat and measures to increase the population size are required.

\section{ACKNOWLEDGEMENTS}

This study was mainly funded by the government of Malaysia under the Tenth and Eleventh Malaysia Plans. We thank the Forestry Department Peninsular Malaysia for providing the National Forest Inventory III data and the State Forestry Departments involved for granting entries to the forest reserves. We thank Tnah LH, Subha B and Tan KK for assistance in genetic work and our supporting staff who helped in the laboratory and field studies.

\section{REFERENCES}

Binks RM, Millar MA \& Byrne M. 2015. Not all rare species are the same: contrasting patterns of genetic diversity and population structure in two narrow-range endemic sedges. Biological Journal of the Linnean Society 114: 873-886. https://doi.org/10.1111/bij.12465.

Brown N, Jennings S, Wheeler P \& Nabe-Nielsen J. 2000. An improved method for the rapid assessment of forest understorey light environments. Journal of Applied Ecology 37: 1044-1053. https://doi.org/10.1046/ j.1365-2664.2000.00573.x.

Chan YM, Tnah LH, Lee SL, Subha B, Lee CT \& Chua LSL. 2018. Limited dispersal and geographic barriers cause population differentiation and structuring in Begonia maxwelliana at both large and small scales. Plant Ecology Eं Diversity 11: 69-83. https://doi.org/ 10.1080/17550874.2018.1471625.

Chan YM, Twyford AD, TNah LH \& Lee CT. 2015. Characterisation of EST-SSR markers for Begonia maxwelliana (Begoniaceae) and cross-amplification in 23 species from 7 Asian sections. Scientia Horticulturae 190: 70-74. http://dx.doi.org/10.1016/j.scienta. 2015.04.012.

CHown SL. 1997. Speciation and rarity: Separating cause from consequence. Pp 91-109 in Kunin WE \& Gaston $\mathrm{KJ}$ (eds) The Biology of Rarity: Causes and Consequences of Rare-Common Differences. Springer Science+Business Media, London.

Chua LSL, Kiew R \& Chan YM. 2009. Assessing conservation status of Peninsular Malaysian Begonias (Begoniaceae). Blumea 54: 94-98. https://doi. org/10.3767/000651909X474131.

Fernández-Mazuecos M, Jiménez-Mejías P, Rotllan-Puig X \& VARGAS P. 2014. Narrow endemics to Mediterranean islands: Moderate genetic diversity but narrow climatic niche of the ancient, critically endangered Naufraga (Apiaceae). Perspectives in Plant Ecology, Evolution and Systematics 16: 190-202. https://doi. org/10.1016/j.ppees.2014.05.003.

Fiedler PL. 1987. Life history and population dynamics of rare and common mariposa lilies (Calochortus Pursh: Liliaceae). Journal of Ecology 75: 977-995. doi:10.2307/2260308.

Fischer M \& Matthies D. 1998. Effects of population size on performance in the rare plant Gentianella germanica. Journal of Ecology 86: 195-204. https:/ / doi. org/10.1046/j.1365-2745.1998.00246.x.

Frankham R, Briscoe DA \& Ballou JD. 2002. Introduction to Conservation Genetics. Cambridge University Press, Cambridge.

Gabrielová J, Münzbergová Z, Tackenberg O \& Chrtek J. 2013. Can we distinguish plant species that are rare and endangered from other plants using their biological traits? Folia Geobotanica 48: 449-466. doi:10.1007/s12224-012-9145-x.

Gaston KJ. 1997. What is rarity? Pp 30-47 in Kunin WE \& Gaston KJ (eds) The Biology of Rarity: Causes and Consequences of Rare-Common Differences. Population and Community Biology Series. Volume 17. Springer, Dordrecht.

Gitzendanner MA \& Soltis PS. 2000. Patterns of genetic variation in rare and widespread plant congeners. American Journal of Botany 87: 783-792. https://doi. org $/ 10.2307 / 2656886$.

Hamrick JL, Godt MJW, Murawski DA \& Loveless MD. 1991. Correlations between species traits and allozyme diversity: implications for conservation biology. Pp 75-86 in Falk DA \& Holsinger KE (eds) Genetics and Conservation of Rare Plants. Oxford University Press, New York.

Hornemann G, Weiss G \& Durka W. 2012. Reproductive fitness, population size and genetic variation in Muscari tenuiflorum (Hyacinthaceae): the role of temporal variation. Flora-Morphology, Distribution, Functional Ecology of Plants 207: 736-743. https:/ / doi. org/10.1016/j.flora.2012.07.005.

Hughes M \& Hollingsworth PM. 2008. Population genetic divergence corresponds with species-level biodiversity patterns in the large genus Begonia. MolecularEcology 17: 2643-2651. doi 10.1111/j.1365294X.2008.03788.x.

Hughes M, Hollingsworth PM \& Miller AG. 2003. Population genetic structure in the endemic Begonia 
of the Socotra archipelago. Biological Conservation 113: 277-284.

KARRON JD. 1987. A comparison of levels of genetic polymorphism and self-compatibility in geographically restricted and widespread plant congeners. Evolutionary Ecology 1: 47-58.

KARRON JD. 1991. Patterns of genetic variation and breeding systems in rare plant species. Pp 87-98 in Falk DA \& Holsinger KE (eds) Genetics and Conservation of Rare Plants. Oxford University Press, New York.

KIEW R. 2005. Begonias of Peninsular Malaysia. Natural History Publications (Borneo) Sdn Bhd, Kota Kinabalu.

Kiew R, Julia S, Rimi R \& Joffre AA. 2015. A Guide to Begonias of Borneo. Natural History Publications (Borneo) Sdn Bhd, Kota Kinabalu.

Kolb A \& Durka W. 2013. Reduced genetic variation mainly affects early rather than late life-cycle stages. Biological Conservation 159: 367-374. https://doi. org/10.1016/j.biocon.2012.11.019.

KRUCKEBERG AR \& RABINOWITZ D. 1985. Biological aspects of endemism in higher plants. Annual Review of Ecology and Systematics 16: 447-479.

Lavergne S, Thompson JD, Garnier E \& Debussche M. 2004. The biology and ecology of narrow endemic and widespread plants: a comparative study of trait variation in 20 congeneric pairs. Oikos 107: 505-518.

Leimu R, Mutikainen PIA, Koricheva J \& Fischer M. 2006. How general are positive relationships between plant population size, fitness and genetic variation? Journal of Ecology 94: 942-952. https://doi.org/10.1111/ j.1365-2745.2006.01150.x.

Quinn GP \& KeOugh MJ. 2002. Experimental Design and Data Analysis for Biologists. Cambridge University Press, Cambridge.
Reed DH \& Frankham R. 2003. Correlation between fitness and genetic diversity. Conservation Biology 17: 230-237. https://doi.org/10.1046/j.1523-1739.2003.01236.x.

Ritland K. 2002. Extensions of models for the estimation of outcrossing rate and gene frequencies using n-independent loci. Heredity 47: 35-52.

Ruilova XR \& MARQues I. 2016. Better common than rare? Effects of low reproductive success, scarce pollinator visits and interspecific gene flow in threatened and common species of Tibouchina (Melastomataceae). Plant Species Biology 31: 288-295. https://doi. org/10.1111/1442-1984.12114.

Rymer PD, Whelan RJ, Ayre DJ, Weston PH \& Russell KG. 2005. Reproductive success and pollinator effectiveness differ in common and rare Persoonia species (Proteaceae). Biological Conservation 123: 521-532. https://doi.org/10.1016/j. biocon.2005.01.002.

SaW LG, Chua LSL, Suhaida M, Yong WSY \& Hamidah M. 2010. Conservation of some rare and endangered plants from Peninsular Malaysia. Kew Bulletin 65: 681-689. https://doi.org/10.1007/s12225-0119251-6.

Twyford AD, Kidner CA \& Ennos RA. 2014. Genetic differentiation and species cohesion in two widespread Central American Begonia species. Heredity 112: 382-390. 10.1038/hdy.2013.116.

Williams SE, Williams YM, VanDerWal J, Isaac JL, Shoo LP \& Johnson CN. 2009. Ecological specialization and population size in a biodiversity hotspot: how rare species avoid extinction. Proceedings of the National Academy of Sciences of the United States of America 106: 19737-19741. https://doi.org/10.1073/ pnas.0901640106. 